\title{
THE LIBERATION OF THE CAMPS
}




\section{THE \\ LIBERATION \\ DF THE CAMPS}

THE END OF THE HOLOCAUST AND ITS AFTERMATH

\section{DAN STONE}

YALE UNIVERSITY PRESS

NEW HAVEN AND LONDON 
Copyright (C) 2015 Dan Stone

All rights reserved. This book may not be reproduced in whole or in part, in any form (beyond that copying permitted by Sections 107 and 108 of the U.S. Copyright Law and except by reviewers for the public press) without written permission from the publishers.

For information about this and other Yale University Press publications, please contact: U.S. Office: sales.press@yale.edu www.yalebooks.com Europe Office: sales@yaleup.co.uk www.yalebooks.co.uk

Typeset in Minion Pro by IDSUK (DataConnection) Ltd

Printed in Great Britain by TJ International Ltd, Padstow, Cornwall

Library of Congress Cataloging-in-Publication Data

Stone, Dan, 1971-

The liberation of the camps: the end of the Holocaust and its aftermath / Dan Stone. pages $\mathrm{cm}$

Includes bibliographical references and index.

ISBN 978-0-300-20457-5

1. World War, 1939-1945-Concentration camps-Liberation. 2. Concentration camps-Europe-History-20th century. 3. Holocaust, Jewish (1939-1945) 4. World War, 1939-1945-Refugees. 5. World War, 1939-1945-Jews. I. Title.

D805.A2S74 2015

940.53'185-dc23

A catalogue record for this book is available from the British Library.

10987654321

iv 